NASZA DERMATOLOGIA Online OUR DERMATOLOGY Online

Source of Support: Nil

Competing Interests: None

\section{MOLLUSCUM CONTAGIOSUM OF SCALP IN A CHILD}

\section{Patricia Chang}

Dermatologist at Hospital General de Enfermedades IGSS and Hospital Ángeles, Guatemala

Corresponding author: Patricia Chang, $\mathrm{MD} \mathrm{PhD}$

pchang2622@gmail.com
We report a male patient of 7 months old with redish papule on his scalp (Fig. 1a, b) the rest of the clinical examination was normal. Personal and family history non contributory.

The lesion of the scalp began 4 months ago asymptomatic but began to grow and bleeding for that reason his pediatrician sent to us to evaluate him.

The diagnosis of nevoxantoendothelioma was done and a biopsy was performed.

The histogical slides showed a lesion become enlarged as a consequence of the accumulation of masses of viral material purplish red bodies of mollusccum contagiosum was seen (Fig. 2).

Molluscum contagiosum is caused by a virus that is a member of the poxvirus family. The infection can get in a number of different ways.

This is a common infection in children although it is rare under the age of one year and occurs when a child comes into direct contact with a lesion. It is frequently seen on the face, neck, armpit, arms, and hands but may occur anywhere on the body including mucous membranes except the palms and soles.

A second peak occurs in young adult due to sexual transmission with involvement of genital and perineal skin [1].

The virus can spread through contact with infected persons, fomites and sexual transmission.

In conditions that involve altered immunity such as atopic dermatitis, corticosteroid and immunosuppressive therapy, sarcoidosis, leukemias, Wiskott Aldrich syndrome and acquired immune deficiency syndrome, atypical lesions of molluscum contagiosum may occur, often reaching a large size on an unusual site [2].

Typically, the lesion of molluscum begins as a small, painless umbilicated papule that may become raised up to a pearly, fleshcolored nodule. The papule often has in the center central core or plug of white, cheesy or waxy material.
The papules are about 2-5 millimeters wide. There is usually no inflammation and subsequently no redness unless you have been digging or scratching at the lesions.

In adults, the lesions are commonly seen on the genitals, abdomen, and inner thigh.

The localization of molluscum contagiosum exclusively on scalp is rare White [3] and Hill, Messina [4] each reported a case of molluscum contagiosum located exclusively on the.

Sometimes the molluscum contagiosum can be only on the scalp or can also be in other sites [5] at the same time, but the single lesion localized on scalp is uncommon

Molluscum contagiosum on the scalp can affect patients in all ages since newborn to adult in old age and in immunocompetent or no immunocompetent persons [6].

This is a little report of molluscum contagiosum of the scalp for its uncommon localization.

\section{REFERENCES}

1. Wetherington RW, Khan ZM, Cockerell CJ: Viral Inection in: Texbook of Dermatopathology Barnill RL Crowson AN. Mc Graw Hill United States 2004:532.

2. Vozmediano JM, Manrique A, Petraglia S, Romero MA, Nieto I: Giant molluscum contagiosum in AIDS. Int J Dermatol. 1996;35:4547.

3. White C: Molluscum Contagiosum of the Scalp. Arch Derm Syphilol. 1930;21:180-1.

4. Hill WR, Messina SJ: Molluscum Contagiosum of the Scalp Report Arch Derm Syphilol. 1949;60:633-5.

5. Baslas RG, Arora SK: Scalp invovlement by Molluscum contagiosum in a child. Indian J Dermatol Venereol Leprol. 1992;58:36.

6. Sun YW, Oh CW, Kim TH: Molluscum contagiosum of the newborn: an unusual presentation. Ann Dermatol. 1998;10:53-5. 


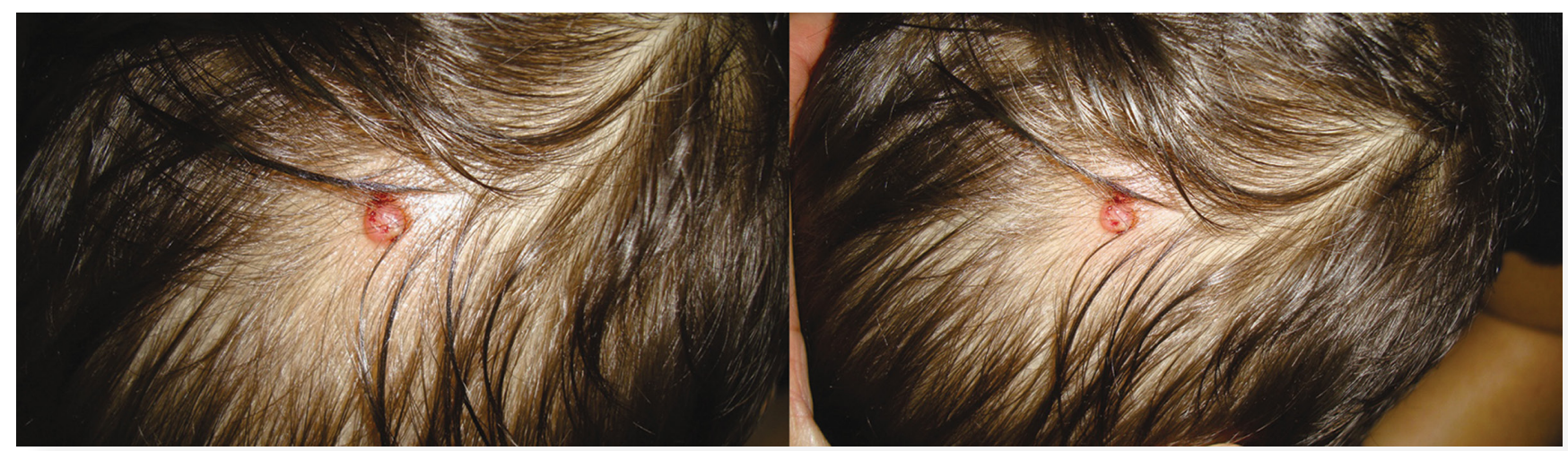

Figure 1a, b. Male patient of 7 months old with redish papule on his scalp

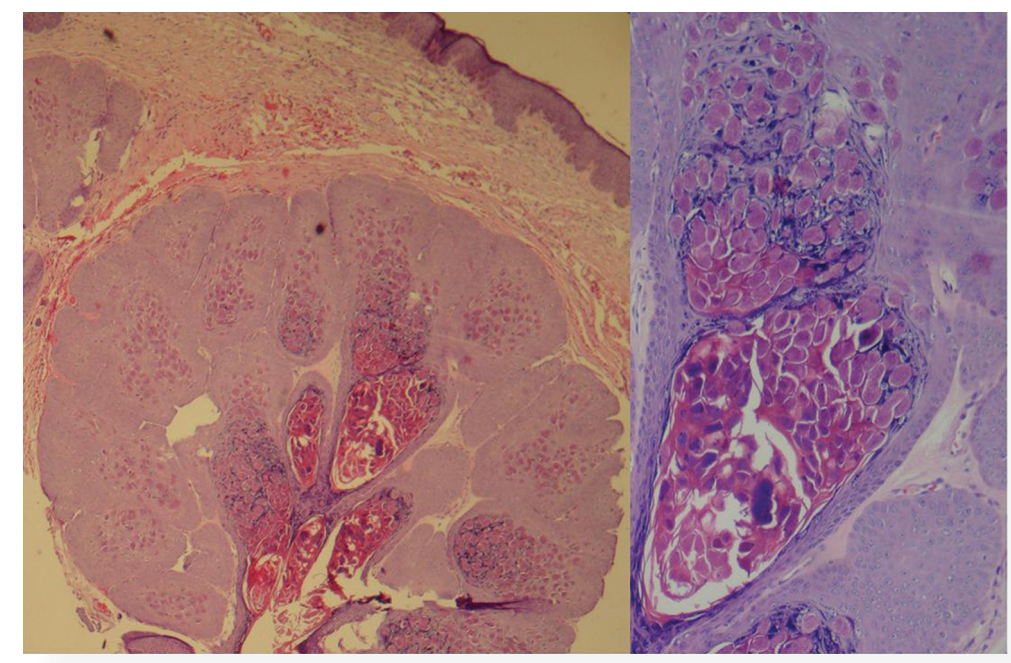

Figure 2. Close up of the scalp lesion

Copyright by Patricia Chang. This is an open access article distributed under the terms of the Creative Commons Attribution License, which permits unrestricted use, distribution, and reproduction in any medium, provided the original author and source are credited. 